UDC 624.012

\title{
BEARING CAPACITY OF STEEL-FIBER-CONCRETE SLABS WITH BIAXIALLY PRESTRESSED REINFORCEMENT
}

\author{
O.D. Zhuravskyi, \\ Candidate of Science (Engineering) \\ Kyiv National University of Construction and Architecture, \\ Kyiv, Povitroflotskyi ave., 31, Kyiv. 03037
}

DOI: $10.32347 / 2410-2547.2020 .105 .292-301$

\begin{abstract}
Experimental-theoretical studies of biaxially prestressed steel-fiber-concrete slabs under the action of a uniformly distributed load were performed. A method for calculating steel-fiberconcrete (SFC) slabs based on the deformation method is proposed. This takes into account stress losses in the reinforcement from creep and shrinkage deformations of reinforced concrete. The increase in compressive strength of steel-fiber-concrete under biaxial compression is also taken into account. The results of calculation of experimental samples and their comparison with the results of experimental researches are given.
\end{abstract}

Keywords: bearing capacity, steel-fiber-concrete, bending moment, curvature, prestressed reinforcement, relative deformations, stresses in reinforcement, stresses in steel-fiber-concrete.

Introduction. Modern construction is impossible without the use of reinforced concrete structures with pre-stressed reinforcement. Fiber reinforcement is used to improve the strength and deformability characteristics of concrete. Among such fibers, steel fiber is the most widely used. It significantly improves the tensile strength of steel-fiber-concrete (SFC). This makes it possible to take into account the operation of the SFC in the stretched cross-sectional area of the bending elements. The current regulations do not provide recommendations for the calculation of the SFC of flat elements that work in two directions. There are no recommendations for the calculation of SFB elements with pre-stressed reinforcement. Research of bearing capacity, crack resistance and deformations of biaxially prestressed SFC plates is practically absent. The aim of the research is to obtain new experimental data of such structures under transverse loading and to develop a method for calculating their bearing capacity.

1. Method of calculating the bearing capacity. To determine the bearing capacity of the plate, we consider a scheme in which the plate is subjected to a uniformly distributed load and pre-compression forces in two directions $P_{x}$ and $P_{y}$ (Fig. 1). The characteristics of reinforcement are accepted according to fig. 2.

The calculation of the carrier definition is performed in two directions, cutting strips of width $b_{x}=S_{x}$ and $b_{y}=S_{y}$. At the first stage, we determine the compressive stress of the SFC, which is transmitted by pre-stressed reinforcement, taking into account the losses from shrinkage and creep of the SFC. The stress-strain state in cross section is shown in fig. 3 . When the central compression stresses and strains in cross section are the same height $\sigma_{c f(1)}=\sigma_{c f(2)}$ and $\varepsilon_{c f(1)}=\varepsilon_{c f(2)}$.

(C) Zhuravskyi O.D. 


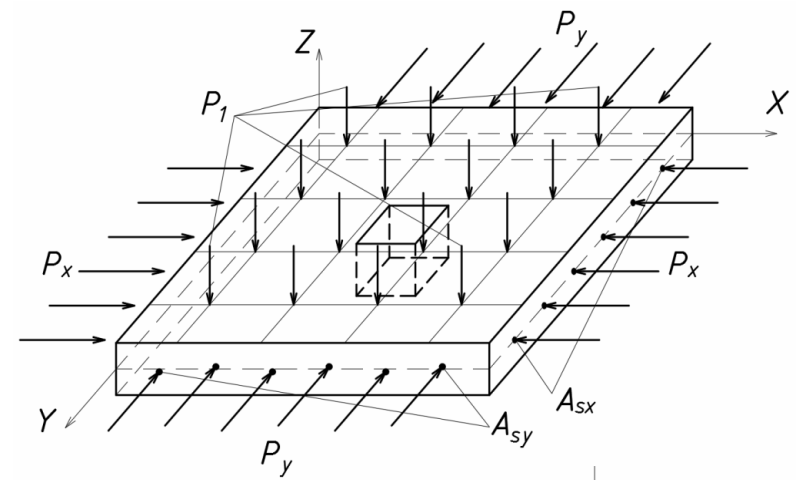

Fig. 1. The loading scheme of the experimental steel-fiber-concrete slab: $P_{1}$ - single vertical load; $P_{x}$ and $P_{y}$ - pre-compression forces along the axes, respectively $X$ and $Y$

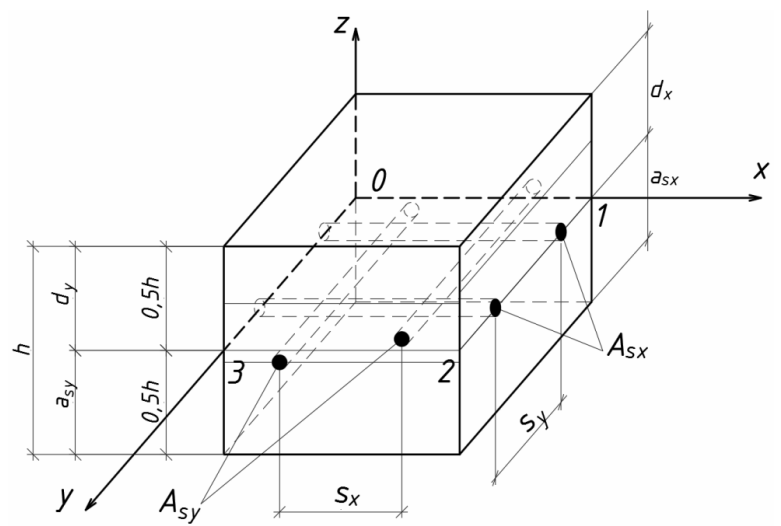

Fig. 2. Characteristics of reinforcement of a single fragment of the plate

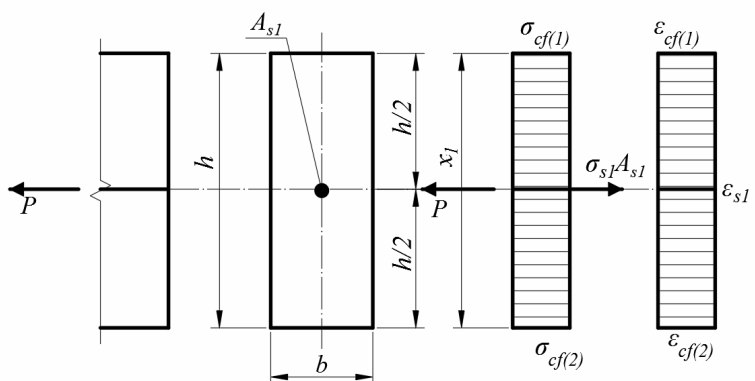

(a)

(b)

Fig. 3. Stress-strain state of a rectangular steel-fiber-concrete section with pre-stressed reinforcement in the center of the section:

(a) - cross section of the element;

(b) - diagram of stresses and strains during the transfer of forces from reinforcement to concrete

After applying a vertical load, the stress-strain state can be divided into 
three stages (Fig. 4).

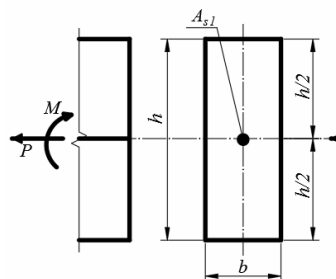

(a)

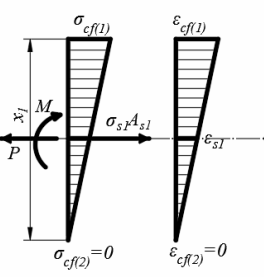

(b)

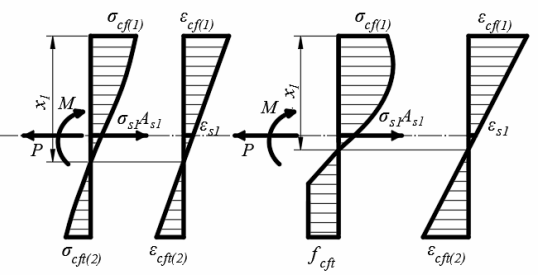

(c)

(d)

Fig. 4. Stress-strain state of a rectangular steel-fiber-concrete section with pre-stressed reinforcement in the center of the section under the action of bending moment: (a) - cross section of the element; (b) - diagram of stresses and strains under the action of bending moment and compressive force at stage I; (c) - plot of stresses and strains under the action of bending moment and compressive force at stage II (stage of crack formation); (d) - diagram of stresses and strains

under the action of bending moment and compressive force at stage III (stage of destruction)

At the first stage at insignificant loading compressive stresses and deformations in the top zone of section increase, and in the bottom zone of section decrease and reach values $\sigma_{c f(2)}=0$ and $\varepsilon_{c f(2)}=0$ (Fig. 4b). At the same time tensile stresses in the reinforcing rod $\sigma_{s 1}$ will decrease

In the second stage, with a further increase in load, the compressive stresses and strains in the upper section of the section increase, and in the lower section of the section there is tension and stresses and strains change sign $-\sigma_{c f(2)}=\sigma_{c f t(2)}$ and $-\varepsilon_{c f(2)}=\varepsilon_{c f t(2)}$ (Fig. 4c). The tensile stresses in the reinforcing rod $\sigma_{s 1}$ are further reduced. At this stage, normal cracks occur and it is taken to calculate the crack resistance and crack width.

In the third stage, with a further increase in load, the compressive stresses and strains in the upper cross-sectional area reach the limit values $\left(\sigma_{c f(1)}=f_{c f}\right.$ and $\left.\varepsilon_{c f(1)}=\varepsilon_{c f u}\right)$, and in the lower cross-sectional area, the tensile and strain stresses reach the limit values $\left(\sigma_{c f t(1)}=f_{c f t}\right.$ and $\varepsilon_{c f(2)}=\varepsilon_{c f t u}$ ) (Fig. 4d). The tensile stresses in the reinforcing rod $\sigma_{s 1}$ are further reduced. This stage is used to calculate the bearing capacity.

The value of the ultimate bending moment in the direction of one axis $i=(x$ or $y$ ) for fiber-reinforced bending elements of rectangular cross-section with pre-stressed reinforcement is recommended to be determined by the formulas:

$$
\begin{gathered}
\frac{b_{i} f_{c f} k_{c i}}{\overline{\aleph_{i}}} \sum_{k=1}^{5} \frac{a_{k}}{k+1} \gamma^{k+1}-\frac{3}{4} b_{i} f_{c f t}\left(h-x_{1, i}\right)+\sigma_{s i} A_{s i}=0, \\
\frac{b_{i} f_{c f} k_{c i}}{\overline{\aleph_{i}^{2}}} \sum_{k=1}^{5} \frac{a_{k}}{k+2} \gamma^{k+2}-\frac{1}{6} b_{i} f_{c f t}\left(h-x_{1 i}\right)^{2}+\sigma_{s i} A_{s i}\left(x_{1}-z_{s i}\right)-M_{i}=0 .
\end{gathered}
$$

In formulas (4.7), (4.8) according to [7]: 
$\gamma=\frac{\varepsilon_{c f(1)}}{\varepsilon_{c f 1}} ; \varepsilon_{c f(1)}$ - relative deformations of the SFC in the compressed crosssectional area; $\varepsilon_{c f(2)}$ - relative deformations of the SFC in the stretched crosssectional area; $\aleph_{i}=\left(\frac{1}{r}\right)_{i}=\frac{\left(\varepsilon_{c(1)}-\varepsilon_{c(2)}\right)_{i}}{h}-$ the curvature of the curved axis in cross section; $x_{1 i}=\frac{\varepsilon_{c f(1)}}{\aleph_{i}}-$ height of the compressed zone $(\mathrm{m}) ; \bar{\aleph}_{i}=\frac{\aleph_{i}}{\varepsilon_{c f 1}}-$ relative curvature; $\sigma_{s p i}=E_{s p i}\left(\aleph_{i}\left(x_{1 i}-z_{s i}\right)-\varepsilon_{p 0 i}\right)$ - stresses in reinforcing rod; $\varepsilon_{p 0 i}$ - relative deformations from the prestress of the reinforcing rod, taking into account all losses; $k_{c i}$ - coefficient that takes into account the increase in the strength of the SFC under biaxial compression and is determined by DBN [1].

The calculation of the ultimate bending moment is performed in the following sequence:

1. In the first step, we determine the relative deformations $\varepsilon_{c f(1)}$ in the most compressed face, taking $\varepsilon_{c f(2)}=0$ (Fig. 4b). To do this, determine the values $\gamma, \aleph_{i}, x_{1 i}, \bar{\aleph}_{i}, \sigma_{s p i}$ and, substituting them in equation (1), select the value $\varepsilon_{c f(1)}$ so that equation (1) is equal to 0 . Next, we substitute the obtained values into equation (2) and determine the value of the moment $M$.

2. In the second step, increase the value $\varepsilon_{c f(1)}$ by $0,1 \varepsilon_{c f(1)}$ and select the value $\varepsilon_{c f(2)}$ so that equation (1) is equal to 0 (Fig. 4c). Next, we substitute the obtained values into equation (2) and determine the value of the moment $M$. The value of the moment $M$ and $\aleph_{i}$ plot on the graph «moment-curvature».

3 . The following steps are performed by analogy with the second, gradually increasing the value $\varepsilon_{c f(1)}$ by $0,1 \varepsilon_{c f(1)}$. The calculations are performed step by step until the value of the moment in the last step is less than in the previous step or the values of the relative deformations in the stretched zone reach the limit values.

2. Strength and deformability characteristics of SFC. The prototypes were made of SFC with a concrete matrix of the same composition. Portland cement of the M400 brand was used. Quartz sand in the ratio $C / P=1 / 3$ was used as a fine aggregate. The water-cement ratio was $W / C=0.62$.

Samples of the first series were reinforced with a mixture of steel fibers of STAFIB 50/1.0 and STAFIB 30/0.6 with anchors at the ends, the percentage of which was $0.5 \%$ by volume of each fiber. The samples of the second series contained $1.0 \%$ by volume of NOVOKON URW 50/1.0 corrugated fibers. Technical characteristics used in the study of steel fibers are given in table 1.

Determination of strength and deformation characteristics of SFC was 
carried out on prisms $75 \times 75 \times 300 \mathrm{~mm}, 100 \times 100 \times 400 \mathrm{~mm}$ and cubes with a rib size of 75 and $100 \mathrm{~mm}$ at the age of 28 days. The tensile strength of the SFC was determined when testing samples of "eights" with a cross section of 40x40 $\mathrm{mm}$ in a rupture machine. As a result of tests, the compressive strength of SFC is $f_{c f k, p r i s m}=13.5 \mathrm{MPa}$ (series I) and $f_{c f k, p r i s m}=10.3 \mathrm{MPa}$ (series II). The tensile strength of SFC is $f_{c f t k}=1.48 \mathrm{MPa}$ (series I) and $f_{c f t k}=1.22 \mathrm{MPa}$ (series II). The initial modulus of elasticity of SFC is $E_{c f}=37158 \mathrm{MPa}$ (series I) and $E_{c f}=18094 \mathrm{MPa}$ (series II).

Technical characteristics of steel fiber

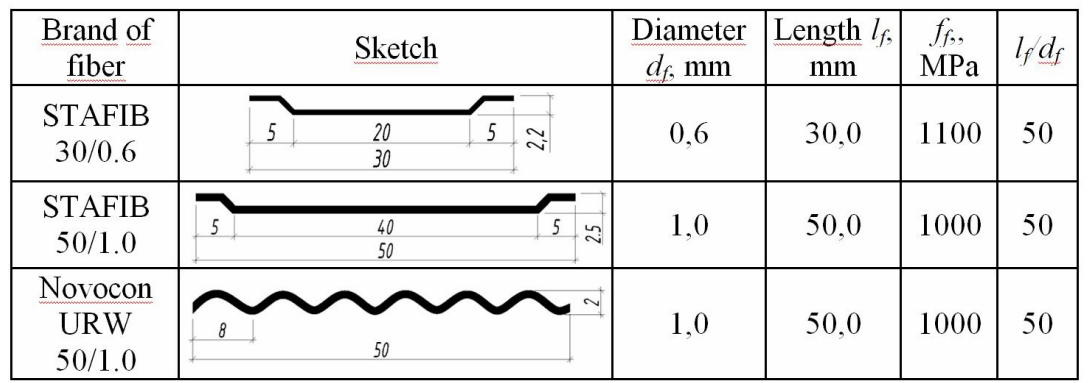

To construct theoretical diagrams " $\sigma-\varepsilon$ " during compression of SFC prisms, the dependence on DBN was used [1]:

$$
\sigma_{c f}=\mathrm{f}_{c f} \sum_{k=1}^{5} a_{k} \eta^{k},
$$

where $\eta=\varepsilon_{c f} / \varepsilon_{c f 1} ; \varepsilon_{c f 1}$ - relative deformations of SFC at maximum stresses; $a_{k}$ - polynomial coefficients, which are determined depending on the experimental value of the prism strength of the SFC according to the method [7] (see Table 2).

Table 2

Polynomial coefficients for SFC undercompression

\begin{tabular}{|c|c|c|c|c|c|}
\hline & $a_{1}$ & $a_{2}$ & $a_{3}$ & $a_{4}$ & $a_{5}$ \\
\hline Series I & 2,94069 & $-3,2747$ & 1,7844 & $-0,50755$ & 0,05713 \\
\hline Series II & 3,17450 & $-3,8567$ & 2,2594 & $-0,64700$ & 0,06970 \\
\hline
\end{tabular}

Diagrams of " $\sigma-\varepsilon$ " at uniaxial compression of SFC prisms of the I and II series are given in fig. 5 .

The relative compressive strains of the SFB were $\varepsilon_{c f 1}=1,78 \times 10^{-3}$ (series I) and $\varepsilon_{c f 1}=1,6 \times 10^{-3}$ (series II); $\varepsilon_{c f u}=2,74 \times 10^{-3}$ (series I) and $\varepsilon_{c f u}=2,56 \times 10^{-3}$ (series II). The relative tensile strains of the SFB were $\varepsilon_{c f t 1}=2,1 \times 10^{-4}$ (series I) and $\varepsilon_{c f t 1}=1,8 \times 10^{-4}$ (series II). 


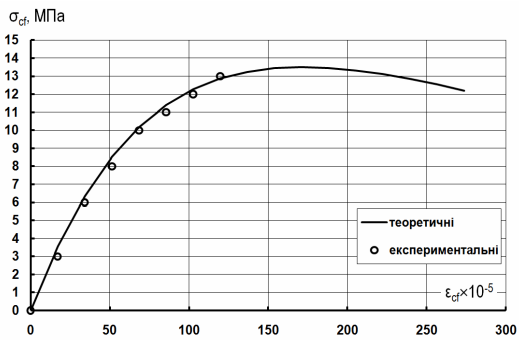

(a)

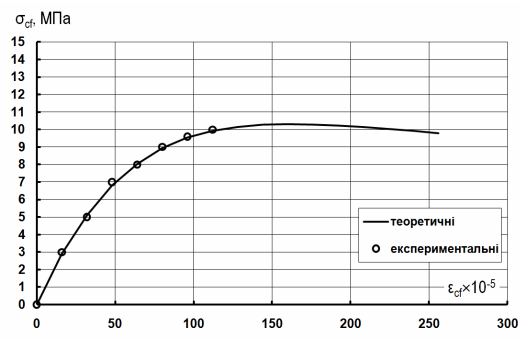

(b)

Fig. 5. Diagrams " $\sigma-\varepsilon$ " at uniaxial compression of SFC prisms of the I series (a) and II series (b)

3. Experimental studies. Experimental studies were performed on plates measuring 40x800x800 mm with prestressed reinforcement Ø5Bp-II in two directions. The compression levels of the test plates are given in table 3. Made two series of plates with different levels of prestress.

Table 3

Compression levels of experimental plates

\begin{tabular}{|c|c|c|c|c|c|c|c|c|}
\hline \multirow{3}{*}{$\begin{array}{l}\text { Series } \\
\text { number }\end{array}$} & \multirow{3}{*}{ Sample name } & \multirow{3}{*}{$\begin{array}{l}\text { Number } \\
\text { of } \\
\text { samples }\end{array}$} & \multicolumn{4}{|c|}{$\begin{array}{c}\text { Compression level along the } \\
\text { axis }\end{array}$} & \multirow{2}{*}{\multicolumn{2}{|c|}{$\begin{array}{l}\text { The number of } \\
\text { reinforcing bars } \\
\text { along the axis }\end{array}$}} \\
\hline & & & \multicolumn{2}{|c|}{ planned } & \multicolumn{2}{|c|}{ actual } & & \\
\hline & & & $\mathrm{X}$ & $\mathrm{Y}$ & $\mathrm{X}$ & $\mathrm{Y}$ & $\mathrm{X}$ & $\mathrm{Y}$ \\
\hline \multirow{4}{*}{ I } & $\mathrm{I}-\mathrm{CII}-0.7 / 0.0$ & 2 & 0.7 & 0.0 & 0.66 & 0 & 9 & 9 \\
\hline & $\mathrm{I}-\mathrm{\Pi II}-0.7 / 0.3$ & 2 & 0.7 & 0.3 & 0.66 & 0.29 & 9 & 6 \\
\hline & $\mathrm{I}-\Pi \mathrm{II}-0.7 / 0.7$ & 2 & 0.7 & 0.7 & 0.66 & 0.66 & 9 & 9 \\
\hline & I-ПII-Y & 2 & - & - & - & - & 9 & 9 \\
\hline \multirow{4}{*}{ II } & П-ПШП-0.7/0.0 & 2 & 0.7 & 0.0 & 0.63 & 0.0 & 9 & 9 \\
\hline & П-ПП-0.7/0.3 & 2 & 0.7 & 0.3 & 0.63 & 0.28 & 9 & 6 \\
\hline & П-ПП-0.7/0.7 & 2 & 0.7 & 0.7 & 0.63 & 0.63 & 9 & 9 \\
\hline & П-ПП-У & 2 & - & - & - & - & 9 & 9 \\
\hline
\end{tabular}

The characteristics of SFB I and II series are given in item 2. Mechanical characteristics of reinforcing steel are as follows: strength limit $\sigma_{u}=1811 \mathrm{MPa}$, conditional yield strength $\sigma_{0,2}=1400 \mathrm{MPa}$, modulus of elasticity $E_{s}=2,0 \times 10^{5} \mathrm{MPa}$.

The plates were loaded by 16 concentrated forces $P_{1}$ evenly over the entire area of the plate with a step of $180 \mathrm{~mm}$ by means of hydraulic jacks through a system of traverses with hinged units. This simulated a uniformly distributed load $q$ (Fig. 6). The slabs were hinged on four sides. The flight along the $X$ and $Y$ axes was $700 \mathrm{~mm}$. During the test, the deformations of the SFB on the lower and upper surfaces of the plates were measured using strain gauges. The deflections of the plates in the center of the plate and the deformation of the supports were also measured using clock-type indicators with a division price of $0.01 \mathrm{~mm}$. The magnitude of the load was recorded on the manometer of the pumping station, to which the hydraulic jacks were connected. 


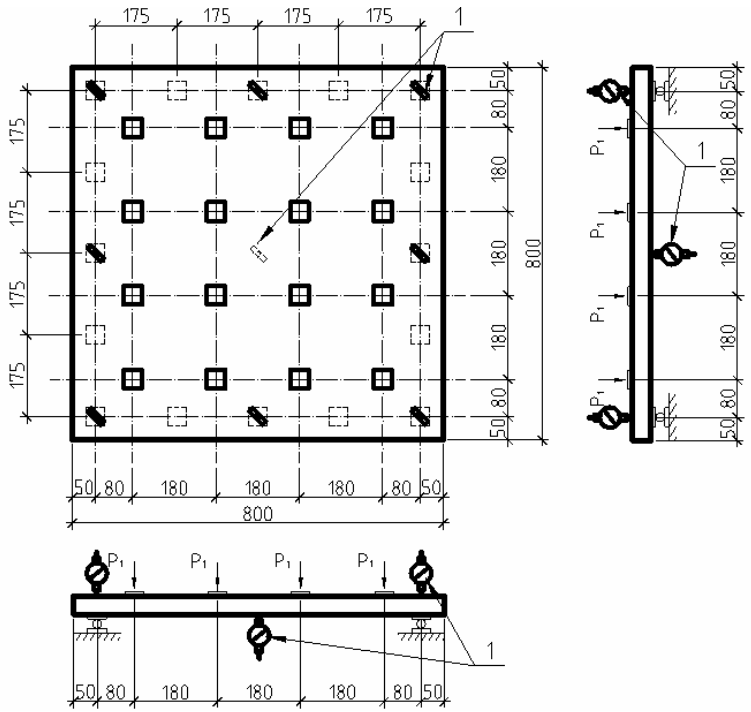

Fig. 6. The scheme of plates loading: 1 - indicators

4. Comparative analysis of experimental and theoretical studies. As a result of the tests, crack-loading loads and loads at which the plates collapsed were obtained (Table 4).

Table 4

Experimental values of loads in the formation of cracks and in the destruction of experimental plates

\begin{tabular}{|c|c|c|c|c|c|c|}
\hline \multirow[t]{2}{*}{ Sample name } & \multicolumn{2}{|c|}{$\begin{array}{c}\text { Load in the } \\
\text { formation of cracks } \\
q_{\text {cro }}, \mathrm{kN} / \mathrm{m}^{2}\end{array}$} & \multicolumn{2}{|c|}{$\begin{array}{l}\text { The load of } \\
\text { destruction } \\
q_{u}, \mathrm{kN} / \mathrm{m}^{2}\end{array}$} & \multicolumn{2}{|c|}{$\begin{array}{c}\text { The moment of } \\
\text { destruction, } \\
M_{\mu}, \mathrm{kNm}\end{array}$} \\
\hline & one plate & $\begin{array}{c}\text { average } \\
\text { value }\end{array}$ & plate & $\begin{array}{c}\text { average } \\
\text { value }\end{array}$ & $\begin{array}{l}\text { experi- } \\
\text { mental }\end{array}$ & $\begin{array}{c}\text { theore- } \\
\text { tical }\end{array}$ \\
\hline $\mathrm{I}-\mathrm{\Pi II}$ & 12,55 & \multirow{2}{*}{13,28} & 20 & \multirow{2}{*}{35,88} & \multirow{2}{*}{0,198} & \multirow{2}{*}{0,188} \\
\hline $\mathrm{I}-\mathrm{\Pi II-}$ & 14,01 & & 36,56 & & & \\
\hline I-III & & \multirow{2}{*}{21,20} & & \multirow{2}{*}{44,46} & \multirow{2}{*}{0,245} & \multirow{2}{*}{0,251} \\
\hline I-III] & 21,54 & & 44,92 & & & \\
\hline I-IIII & 22,19 & \multirow{2}{*}{22,76} & 51,50 & \multirow{2}{*}{51,89} & \multirow{2}{*}{0,286} & \multirow{2}{*}{0,283} \\
\hline $\mathrm{I}-\mathrm{III}$ & 23,33 & & 53,10 & & & \\
\hline I-IIII & 10,70 & \multirow{2}{*}{11,04} & & \multirow{2}{*}{34,45} & \multirow{2}{*}{0,190} & \multirow{2}{*}{0,186} \\
\hline $\mathrm{I}-\mathrm{\Pi l}$ & & & 34,76 & & & \\
\hline II-ПII & 12,53 & \multirow{2}{*}{12,59} & 33,05 & \multirow{2}{*}{33,85} & \multirow{2}{*}{0,187} & \multirow{2}{*}{0,184} \\
\hline ПI-ПII-0. & & & 34,66 & & & \\
\hline II-ПII & 18,77 & \multirow{2}{*}{18,90} & 42,29 & \multirow{2}{*}{42,63} & \multirow{2}{*}{0,235} & \multirow{2}{*}{0,233} \\
\hline ПI-ПII- & 19,04 & & 42,97 & & & \\
\hline П-ППІ-0.7/0.7-1 & 22,76 & \multirow{2}{*}{21,80} & 49,19 & \multirow{2}{*}{48,42} & \multirow{2}{*}{0,267} & \multirow{2}{*}{0,262} \\
\hline ПI-ПII-0.7/0.7-2 & 20,83 & & 47,26 & & & \\
\hline ПI-ПIП-У -1 & 9,45 & \multirow{2}{*}{9,79} & 29,14 & \multirow{2}{*}{30,29} & \multirow{2}{*}{0,167} & \multirow{2}{*}{0,163} \\
\hline ПI-ПII-У-2 & 10,13 & & 31,43 & & & \\
\hline
\end{tabular}


The following conclusions can be drawn when analyzing the experimental and theoretical values of the maximum limits. The difference in experimental and theoretical values was $1,1 \ldots 2,5 \%$. The bearing capacity of $\Pi \Pi-0.7 / 0.7$ slabs was higher than ПП-0.7/0.3 slabs by $12,4 \ldots 12,7 \%$, from $\Pi \Pi-0.7 / 0.0$ slabs by $42,4 \ldots 55,5 \%$. The bearing capacity of ПП-У unstressed slabs was $1.55 \ldots 1.61$ times lower than ПП-0.7/0.7 slabs, $1,35 \ldots 1,43$ times lower than ПП-0.7/0.3 slabs and $1,01 \ldots 1,13$ times from ПП-0.7/0.0 plates.

Conclusion. The proposed method of calculating the bearing capacity of SFC plates takes into account the real diagram " $\sigma-\varepsilon "$ uniaxial and biaxial compression of reinforced concrete. The effect of lateral compression on the compressive strength of the SFC is also taken into account. The influence of biaxial pre-compression of SFC on the bearing capacity of slabs with prestressed reinforcement has been experimentally and theoretically confirmed.

\section{REFERENCES}

1. DBN V.2.6-98:2009. Konstruktsii budynkiv i sporud. Betonni ta zalizobetonni konstruktsii. Osnovni polozhennia. (DBN B.2.6-98: 2009. Constructions of houses and buildings. Concrete and reinforced concrete structures. Substantive provisions) - K.: Minrehionbud Ukrainy, 2009. -71 s.

2. DSTU B V.2.6.-156:2010. Konstruktsii budynkiv i sporud. Betonni ta zalizobetonni konstruktsii z vazhkoho betonu. Pravyla proektuvannia. (DSTU B B.2.6.-156: 2010. Constructions of houses and buildings. Concrete and reinforced concrete structures made of heavy concrete. Design rules) -K.: Minrehionbud Ukrainy, 2011. -118 s.

3. DSTU-N EN 1992-1-1:2010. Budivelni materialy i konstruktsii. Proektuvannia zalizobetonnykh konstruktsii. Osnovni polozhennia. Zahalni pravyla proektuvannia (EN 1992-1-1:2004, IDT). (DSTU-N EN 1992-1-1: 2010. Building materials and structures. Design of reinforced concrete structures. Substantive provisions. General design rules (EN 1992-1-1:2004, IDT)) - Kyiv: Minrehionbud Ukrainy, 2010. - S.341.

4. DSTU-N B V.2.6-218:2016. Nastanova z proektuvannia ta vyhotovlennia konstruktsii $\mathrm{z}$ dyspernoarmovanoho betonu. (DSTU-N B B.2.6-218: 2016. Guidelines for the design and manufacture of structures of dispersed reinforced concrete) - Kyiv: DP «UkrNDNTs», 2017. - S. 32.

5. Horobets A.M. Doslidzhennia vtrat poperednoho napruzhennia v stalefibrobetonnykh plytakh pry odnoosnomu ta dvokhosnomu obtysku (Investigation of prestress losses in SFC plates with uniaxial and biaxial compression) / Horobets A.M., Zhuravskyi O.D. // Resursoekonomni materialy, konstruktsii, budivli ta sporudy: Zbirnyk naukovykh prats. Vyp. 16, chastyna 2. - Rivne, 2008, S. 123-128.

6. Horobets A.M. Mitsnist ta trishchynostiikist dvokhosno poperedno-napruzhenykh stalefibrobetonnykh plyt pry poperechnomu zghyni (Strength and crack resistance of biaxially prestressed SFC plates at transverse bending) / Horobets A.M., Zhuravskyi O.D. // Budivelni konstruktsii. Teoriia i praktyka: Zbirnyk naukovykh prats. -K., KNUBA, -Vyp. 1., 2017, S. 181-186.

7. Proektuvannia zalizobetonnyz konstruktsii. Posibnyk (Design of reinforced concrete structures. Manual) / A.M.Bambura, HR.Sazonova, O.V. Dorohova, O.V.Voitsekhivskyi / Za red. A.M. Bambura. Kyiv: Maister knyh, 2018. 240 s.

8. EN 1992-1-1. Eurocode 2: Design of Concrete Structures. Part 1-1: General Rules and Rules for Buildings. [Final Draft, December, 2004]. Brussels: CEN. 2004. 225 p.

9. Zhuravskyi $O$. Experimental and theoretical studies of biaxially prestressed steel-fiberconcrete slabs / O.Zhuravskyi, A.Gorobetc // USEFUL online journal, vol. 2, no. 3, pp. 1014, Oct. 2018. DOI: https://doi.org/10.32557/useful-2-3-2018-0003. 
Журавський О.Д.

\section{НЕСУЧА ЗДАТНІСТЬ СТАЛЕФІБРОБЕТОННИХ ПЛИТ 3 ДВОХОСНО ПОПЕРЕДНЬО-НАПРУЖЕНОЮ АРМАТУРОЮ}

Метою досліджень $є$ отримання нових експериментальних даних таких конструкцій при поперечному навантаженні та розробка методики розрахунку їх несучої здатності.

Виконано експериментально-теоретичні дослідження двохосно попередньо-напружених сталефібробетонних плит при дії рівномірно-розподіленого навантаження. Експериментальні дослідження виконувались на плитах розміром 40x800x800 мм 3 попередньо напруженою арматурою Ø5Вр-ІІ в двох напрямках. Зразки першої серії армувались сумішшю сталевих фібр марки STAFIB 50/1.0 та STAFIB 30/0.6 із анкерами на кінцях, процентне відношення яких становило по 0,5\% по об'єму кожної фібри. Зразки другої серії містили 1,0\% за об’ємом хвилястих фібр марки NOVOKON URW 50/1.0.

Запропонована методика розрахунку сталефібробетонних (СФБ) плит на основі деформаційного методу. При цьому враховується реальна діаграми «б-є» при одноосному та двохосному стиску сталефібробетону та підвищення міцності сталефібробетону на стиск в умовах двохосного обтиску. Також враховуються втрати напружень в арматурі від деформацій повзучості та усадки сталефібробетону. Наведені результати розрахунку дослідних зразків та порівняння іх з результатами експериментальних досліджень. Вони показали достатню збіжність. Різниця становила $1,1 \ldots 2,5 \%$. Встановлено, що несуча здатність двохосно попередньо напружених плит вища від ненапружених плит в 1,55...1,61 рази та на $42,4 \ldots 55,5 \%$ від одноосно напружених плит.

Ключові слова: несуча здатність, сталефібробетон, згинальний момент, кривизна, попередньо-напружена арматура, відносні деформації, напруження в арматурі, напруження в сталефібробетоні.

\section{Zhuravskyi O.D.}

\section{BEARING CAPACITY OF STEEL-FIBER-CONCRETE SLABS WITH BIAXIALLY PRESTRESSED REINFORCEMENT}

The aim of the research is to obtain new experimental data of biaxially prestressed steel-fiberconcrete slabs under transverse loading and to develop a method for calculating their bearing capacity.

Experimental-theoretical studies of biaxially prestressed steel-fiber-concrete slabs under the action of a uniformly distributed load were performed. Experimental studies were performed on plates measuring 40x800x800 mm with prestressed reinforcement $65 \mathrm{Bp}-\mathrm{II}$ in two directions. Samples of the first series were reinforced with a mixture of steel fibers of STAFIB 50/1.0 and STAFIB 30/0.6 with anchors at the ends, the percentage of which was $0.5 \%$ by volume of each fiber. The samples of the second series contained $1.0 \%$ by volume of NOVOKON URW 50/1.0 corrugated fibers.

A method for calculating steel-fiber-concrete (SFB) slabs based on the deformation method is proposed. This takes into account the real diagram " $\sigma-\varepsilon$ " for uniaxial and biaxial compression of steel-fiber-concrete and increase the compressive strength of steel-fiber-concrete under conditions of biaxial compression. Stress losses in the reinforcement from creep and shrinkage deformations of steel-fiber-concrete are also taken into account. The results of calculation of experimental samples and their comparison with the results of experimental researches are given. They showed sufficient convergence. The difference was $1.1 \ldots 2.5 \%$. It is established that the bearing capacity of biaxially prestressed slabs is $1.55 \ldots 1.61$ times higher than unstressed slabs and $42.4 \ldots 55.5 \%$ higher than uniaxially stressed slabs.

Keywords: bearing capacity, steel-fiber-concrete, bending moment, curvature, prestressed reinforcement, relative deformations, stresses in reinforcement, stresses in steel-fiber-concrete. 


\section{УДК 624.012}

Журавський О.Д. Несуча здатність сталефібробетонних плит 3 двохосно попередньонапруженою арматурою // Опір матеріалів і теорія споруд: наук.-тех. збірн. - К.: КНУБА, 2020. - Вип.105. - С. 292-301. - Англ.

Запропонована методика розрахунку сталефібробетонних плит на основі деформаційного методу. При цьому враховуються втрати напружень в арматурі від деформацій повзучості та усадки сталефібробетону. Також враховується зростання міцності сталефібробетону на стиск в умовах двохосного обтиску. Наведені результати розрахунку дослідних зразків та порівняння їх з результатами експериментальних досліджень.

Табл. 4. Іл. 6. Бібліогр. 9 назв.

\section{UDC 624.012}

Zhuravskyi O.D. Bearing capacity of steel-fiber-concrete slabs with biaxially prestressed reinforcement // Strength of Materials and Theory of Structures: Scientific-and-technical collected articles. - K.: KNUBA, 2020. - Issue 105. - P. 292-301.

The method of calculation of steel-fiber-concrete slabs on the basis of the deformation method is offered. This takes into account stress losses in the reinforcement from creep and shrinkage deformations of steel-fiber-concrete. The increase in compressive strength of steel-fiber-concrete under biaxial compression conditions is also taken into account. The results of calculation of experimental samples and their comparison with the results of experimental researches are given. Tabl. 4. Fig. 6. Ref. 9.

Автор (науковий ступінь, вчене звання, посада): кандидат технічних наук, доцент, завідувач кафедри залізобетонних та кам'яних конструкиій КНУБА ЖУРАВСБКИЙ Олександр Дмитрович.

Адреса: 03037 Украӥна, м. Київ, Повітрофлотський проспект 31, КНУБА, кафедра залізобетонних та кам'яних конструкцій, Журавський Олександр Дмитрович.

Робочий тел.: +38(044) 248-48-42;

Мобільний тел.: +38(067) 508-60-64;

E-mail: zhuravskyi.od@knuba.edu.ua

ORCID ID: https://orcid.org/0000-0001-7065-3312 